\title{
Pengembangan kecerdasan kewargaan berbasis literasi humanitas: Suatu alternatif membangun keadaban publik
}

\section{Kusnadi}

Universitas Terbuka, Tangerang Selatan, Indonesia

\begin{tabular}{ll}
\hline INFORMASI ARTIKEL & ABSTRAK \\
Sejarah Artikel: & Salah satu kegagalan pendidikan untuk menghasilkan kecerdasan kewargaan tercermin \\
Diterima: $20 / 12 / 2021$ & dari krisis keadaban publik. Pendidikan menempatkan terlalu banyak penekanan pada \\
Disetujui: $31 / 01 / 2022$ & kecerdasan individu sementara mengabaikan upaya untuk menghubungkan keragaman \\
& kecerdasan pribadi ke dalam kecerdasan kolektif kewargaan. Akibatnya, banyak orang \\
Kata kunci: & yang tidak sadar akan hak dan kewajibannya. Selain itu, ada perilaku lain dalam \\
Kecerdasan Kewargaan & masyarakat yang tidak mencerminkan keadaban. Penistaan, hinaan, bahkan ancaman \\
Literasi Humanitas & akhir-akhir ini sudah menjadi wacana publik di sejumlah tempat di Indonesia. Banyak \\
Keadaban Publik & orang mempublikasikan foto, karikatur, slogan, dan gambar lainnya di media sosial \\
Keywords : & yang mencerminkan atau berpotensi memancing kebencian dan kemarahan. Oleh \\
Citizenship Intelligence & karena itu, pendidikan kecerdasan kewargaan berdasarkan Pancasila merupakan \\
Humanity Literacy & sarana yang paling efektif untuk membina keadaban masyarakat. Pengembangan \\
Public Civilization & kecerdasan kewargaan lebih fundamental bagi suatu bangsa, untuk itu perlu \\
dikembangkan suatu literasi yang mampu mengantarkan untuk mencapai hidup yang \\
lebih mulia dan beradab, yaitu literasi humanitas. Literasi humanitas merupakan muara \\
dari literasi data dan teknologi bagi pembelajar abad 21 untuk kehidupan yang lebih \\
mulia dan beradab Pendidikan Kewarganegaraan memiliki peran sentral dalam \\
membangun kualitas pendidikan di Indonesia, khususnya pengembangan literasi \\
humanitas. Metode yang digunakan dalam analisis pembahasan ini adalah studi \\
pustaka. Dalam artikel ini membahas tentang kecerdasan kewargaan suatu tantangan, \\
literasi humanitas sebagai solusi proses pendidikan kecerdasan kewargaan, dan \\
pengembangan kecerdasan kewargaan melalui literasi humanitas dan peran literasi \\
humanitas membentuk keadaban publik dalam konteks Indonesia.
\end{tabular}

ABSTRACT

One of the failures of education to produce civic intelligence is reflected in the crisis of public civilization. Education places too much emphasis on individual intelligence while neglecting attempts to link the diversity of personal intelligence into civic collective intelligence. As a result, many people are not aware of their rights and obligations. In addition, there are other behaviors in society that do not reflect civility. Blasphemy, insults, and even threats have recently become part of public discourse in a number of places in Indonesia. Many people publish photos, caricatures, slogans, and other images on social media that reflect or have the potential to provoke hatred and anger. Therefore, civic intelligence education based on Pancasila is the most effective means of fostering community civility. The development of civic intelligence is more fundamental for a nation, for which it is necessary to develop a literacy that is able to lead to a more noble and civilized life, namely human literacy. Humanity literacy is the estuary of data and technology literacy for 21st-century learners for a more noble and civilized life. Citizenship education has a central role in building the quality of education in Indonesia, especially the development of human literacy. The method used in the analysis of this discussion is a literature study. In this article, we discuss civic intelligence as a challenge, human literacy as a solution to the civic intelligence education process, the development of civic intelligence through human literacy, and the role of human literacy in shaping public civility in the Indonesian context.

\section{Pendahuluan}

Krisis pada kedirian yang bersifat publik mencerminkan kelalaian dunia pendidikan dan pembudayaan mengembangkan kecerdasan kewargaan, pendidikan terlalu menekankan kecerdasan individu dengan mengabaikan usaha menautkan keragaman kecerdasan personal ke dalam kecerdasan kolektif kewargaan. Akibatnya, banyak masyarakat yang tidak sadar akan kewajiban dan 
haknya. Selain itu juga banyaknya perilaku yang tidak mencerminkan keadaban dalam bermasyarakat (Latif, 2015). Akhir-akhir ini, Di media sosial sering kita temui orang komentar marah-marah, mengeluarkan bahasa kasar, hanya ketika membaca sebuah judul dari tautan yang dibagikan. Keengganan untuk membaca berita secara utuh merupakan salah satu indikator kalau kita tidak lagi memiliki tradisi tabayyun. Kita menjadi mudah menghujat sesuatu yang berbeda tanpa benar-benar tahu permasalahannya.

Berbagai kasus anarkisme verbal maupun fisik (perundungan, perisakan) menunjukkan ada krisis akut di masyarakat kita menyangkut keadaban publik (public civility). Publik yang beradab ditandai dengan bagaimana mereka memahami yang lain (the others) yang menjadi bagian integral dalam diri mereka (masyarakat). Moralitas adalah unsur pertama dalam membangun keadaban publik. Dalam negara Indonesia yang dikenal sebagai bangsa yang ramah, kini seperti absen dalam masyarakat kita, digantikan perasaan paranoid (curiga) kepada yang lain. Masyarakat yang dipenuhi kecurigaan rentan menghadirkan aksi destruktif ketika apa yang diyakininya dikoyak-koyak oleh pihak lain (Fu'adi, 2016; Munif, 2017) . Dari tingkatan elitis hingga masyarakat arus bawah, degradasi moral menjadi benalu dan bahaya laten yang siap meledak kapan saja. Sangat mungkin tindakan main hakim sendiri merupakan ekspresi ketidakpercayaan pada lembaga hukum dan aparat. Hukum yang diidealkan tanpa pandang bulu, dianggap masih tumpul ke atas dan tajam ke bawah.

Berbagai kasus hukum yang menjerat para elite seperti menguap ditelan waktu. Proses pengadilan berlarut-larut, bahkan kini populer pra peradilan untuk menggugat dakwaan. Kalau pun ditahan, mendapatkan remisi, sehingga keluar penjara sebelum masa tahanan semestinya. Kondisi seperti itu membuat rakyat muak. Namun mereka tidak memiliki saluran ke vertikal (struktur atas). Rasa muak layaknya api dalam sekam. Jadilah kemuakan itu berekses kepada sesama jelata, menjadi konflik horizontal. Pengadilan jalanan dipandang lebih cepat memberikan kepastian dibanding pengadilan negara. Anehnya sikap keramahan masih ada ketika masyarakat hadir secara individu. Keadaban individu (personal civility) masih terjaga hingga hari ini. Yang menggelisahkan adalah keadaban publik ( publik civility) hilang ketika masyarakat tersebut berkumpul menjadi kekuatan massa (Munif, 2017). Berkaitan dengan masalah yang terjadi dalam masyarakat tersebut perlu adanya keterlibatan positif dan produktif, warga negara dituntut memiliki kecerdasan bukan sekadar kecerdasan personal tetapi juga mencakup kecerdasan kewargaan. Kecerdasan kewargaan dapat dilihat dari beberapa atribut yang melekat, yaitu: kompetensi mengemban tugas kewargaan, memahami kewajiban dan hak warga negara, mampu menempatkan keunggulan pribadi dalam harmoni kemajuan bersama, mampu mencari titik temu dalam perbedaan, serta memenuhi panggilan keterlibatan dalam urusan publik (Budimansyah, 2008).

Kecerdasan Kewargaan merupakan kemampuan seseorang untuk memainkan peran dirinya secara proaktif sebagai warga negara dan warga masyarakat dalam tata kehidupan yang kompleks dengan berbasiskan identitas normatif bangsa. Seseorang yang memiliki kecerdasan kewarganegaraan akan menunjukkan performance sebagai warga negara yang peduli terhadap kondisi sosial, jujur dalam menyikapi berbagai fenomena yang ada, kritis terhadap kondisi yang ada, serta tangguh dalam menghadapi berbagai persoalan kehidupan yang dialaminya. Jika kecerdasan kewarganegaraan ini tumbuh subur dalam diri seseorang, maka akan menjadikan dia sosok warga negara yang baik (good citizenship). Dengan demikian kunci dari pembentukan warga negara yang mampu mengembangkan keadaban publik adalah Civic Intelligence (Masrukhi, 2018).

Pendidikan merupakan salah satu proses membentuk manusia Indonesia yang cerdas sekaligus berkarakter. Kondisi tersebut sesuai dengan fungsi dan tujuan Pendidikan Nasional yang tercantum dalam Undang-Undang Nomor 20 tahun 2003 Bab 2 Pasal 3, disebutkan bahwa Pendidikan Nasional berfungsi mengembangkan kemampuan dan membentuk watak serta peradaban bangsa yang bermartabat dalam rangka, mencerdaskan kehidupan bangsa, bertujuan untuk berkembangnya potensi peserta didik agar menjadi manusia yang beriman dan bertakwa kepada Tuhan Yang Maha Esa, berakhlak mulia, sehat, berilmu, cakap, kreatif, mandiri dan menjadi warga negara yang demokratis serta bertanggung jawab, untuk itu diperlukan suatu literasi yang mampu untuk mewujudkan tujuan tersebut dalam kehidupan nyata. Literasi tersebut adalah literasi humanitas.

Literasi humanitas menjadi hal yang penting dalam bertahan di era ini, tujuannya adalah agar manusia bisa berfungsi dengan baik di lingkungan manusia dan dapat memahami interaksi dengan sesama manusia (Alvermann, 2002; Diaz \& Walsh, 2018; Qiyou, 2017). Literasi humanitas adalah menjadi akhir dari literasi data dan teknologi karena pada hakikatnya seorang pembelajar abad ke-21 
adalah sumber daya manusia yang melek data dan teknologi, serta mampu menggunakannya untuk hidup yang lebih mulia (Budimansyah, Suharto, \& Nurulpaik, 2019). Interaksi tersebut dapat dilihat di dunia pendidikan khususnya di lingkungan sekolah. Untuk itu, tugas dunia pendidikan saat ini melalui proses pembelajarannya bukan hanya menekankan pada penguatan kompetensi literasi lama, tetapi secara simultan mengokohkan pada penguatan literasi baru yang menyatu dalam penguatan kompetensi bidang keilmuan dan keahlian atau profesi (Khlaisang \& Koraneekij, 2019), literasi humanitas yang saat ini menjadi trend pengimplementasian dalam menghadapi revolusi industri 4.0 (Deliani, Sulistyawati, \& Kurniawan, 2018; Sanjayanti, Qondias, Wardana, \& Darmayanti, 2018).

Untuk menumbuhkan sikap atau perilaku yang mencerminkan literasi humanitas maka diperlukan suatu proses pendidikan yang relatif sesuai dengan konsep pendidikan yang berfungsi membentuk warga negara yang berkarakter, yaitu Pendidikan Kewarganegaraan. Keterkaitan Pendidikan Kewarganegaraan terhadap pengembangan karakter dikemukakan oleh Winataputra, bahwa pendidikan kewarganegaraan memiliki dimensi - dimensi yang tidak bisa dilepaskan dari aspek pembentukan karakter dan moralitas publik. Pendidikan kewarganegaraan bertujuan untuk membangun karakter (character building) Bangsa Indonesia yang antara lain:

a. Membentuk kecakapan partisipasi warga negara yang bertanggung jawab dalam kehidupan berbangsa dan bernegara.

b. Menjadikan warga negara yang cerdas, aktif dan demokratis, namun tetap memiliki komitmen menjaga persatuan dan integritas bangsa, dan,

c. Mengembangkan kultur demokrasi yang berkeadaban, yaitu kebebasan, persamaan, toleransi, dan bertanggung jawab (Somantri \& Udin Saripudin Winataputra, 2017).

Oleh karena itu, pendidikan kecerdasan kewargaan berlandaskan Pancasila merupakan solusi terbaik untuk membentuk keadaban publik. Pengembangan kecerdasan kewargaan lebih fundamental bagi suatu bangsa (Latif, 2015), untuk itu perlu dikembangkan suatu literasi yang mampu mengantarkan untuk mencapai hidup yang lebih mulia dan beradab, yaitu literasi humanitas. Literasi humanitas merupakan muara dari literasi data dan teknologi bagi pembelajar abad 21 untuk kehidupan yang lebih mulia dan beradab.

Pendidikan Kewarganegaraan memiliki peran sentral dalam membangun kualitas pendidikan di Indonesia, khususnya pengembangan literasi manusia. Berdasarkan latar belakang tersebut muncul suatu permasalahan tantang bagaimana keadaban publik mampu di kembangkan melalui kecerdasan kewargaan dengan menumbuhkembangkan literasi humanitas supaya tercipta kehidupan bermasyarakat yang lebih mulia dan beradab. Dalam artikel ini membahas tentang kecerdasan kewargaan suatu tantangan, literasi humanitas sebagai solusi proses pendidikan kecerdasan kewargaan, dan pengembangan kecerdasan kewargaan melalui literasi humanitas dan peran literasi humanitas membentuk keadaban publik dalam konteks Indonesia.

\section{Metode}

Metode dapat juga berupa cara yang digunakan untuk menyelesaikan permasalahan dalam artikel. Panjang metode 10 persen dari keseluruhan artikel. Metode yang digunakan dalam analisis pembahasan ini adalah studi pustaka. Studi kepustakaan adalah kajian teoritis, referensi serta literatur ilmiah lainnya yang berkaitan dengan budaya, nilai dan norma yang berkembang pada situasi sosial yang diteliti. (Sugiyono, 2015). Studi Kepustakaan mengadakan penelitian dengan cara mempelajari dan membaca literatur-literatur yang ada hubungannya dengan permasalahan yang menjadi obyek penelitian.

Dalam metode studi pustaka penulis akan membahas mengenai sumber-sumber yang masuk ke dalamnya. Dalam studi kepustakaan maka akan melibatkan semua jenis literatur untuk dijadikan referensi. Maka dalam hal ini ada banyak sumber informasi bisa dikaji, diantaranya adalah: jurnal ilmiah, buku, informasi media massa, dan internet. Dalam melakukan penelitian dengan metode studi pustaka, penulis harus mempelajari berbagai referensi yang terkait dengan materi pembahasan. Proses ini sangat penting karena akan memberikan warna pengayaan analisis serta meningkatkan kualitas artikel yang ditulis. Tujuan dari penggunaan metode studi pustaka adalah: Menemukan suatu masalah atau topik, mencari informasi yang relevan, mengkaji teori yang relevan, mencari landasan teori, dan memperdalam pemahaman dan pengetahuan penulis (Muktaf, 2016). 


\section{Hasil dan Pembahasan}

\section{Kecerdasan Kewargaan Sebagai Identitas Normatif Bangsa}

Kecerdasan kewargaan merupakan kemampuan seseorang untuk memainkan peran dirinya secara proaktif sebagai warga negara dan warga masyarakat dalam tata kehidupan yang kompleks dengan berbasiskan identititas normatif bangsa. Seseorang yang memiliki kecerdasan kewarganegaraan akan menunjukkan performance sebagai warga negara yang peduli terhadap kondisi sosial, jujur dalam mensikapi berbagai fenomena yang ada, kritis terhadap kondisi yang ada, serta tangguh dalam menghadapi berbagai persoalan kehidupan yang dialaminya. Jika kecerdasan kewarganegaraan ini tumbuh subur dalam diri seseorang, maka akan menjadilah dia sosok warga negara yang baik (good citizenship). Dengan demikian kunci dari pembentukan warga negara yang baik adalah Civic Intelligence (Masrukhi, 2018).

Kecerdasan kewargaan sudah ada dan bentuk potensial dari kecerdasan kolektif yang didedikasikan untuk mendamaikan masalah masyarakat secara kolektif (Schuler, 2014). Perspektif intelijen sipil telah membantu menciptakan berbagai kerangka dan model yang dapat menginformasikan analisis dan desain melalui pendekatan Al-Qur'an yang disebarkan dengan media interaktif berbasis android. Perubahan cepat dalam informasi dan komunikasi, baik kuantitatif maupun kualitatif, yang dilakukan oleh umat manusia yang besar dan berkembang selama beberapa dekade terakhir, secara historis kompleks, langka, kurang bertenaga, dan terlalu terspesialisasi. Komputer dan perangkat pintar lainnya sekarang sangat diperlukan saat ini sebagai aspek kehidupan sehari-hari. Meskipun dunia semakin mengglobal dan saling berhubungan, banyak masalah masih menghantui umat manusia (Rohman \& Jarudin, 2021).

\section{Literasi Humanitas Trend Pengimplementasian Dalam Menghadapi Revolusi Industri 4.0}

Literasi humanitas adalah landasan dasar yang mewadahi dua jenis literasi lain, yaitu litrasi data dan literasi teknologi (Davenport, Watson, \& Cannon, 2019). Artinya, baik data maupun teknologi harus dipahami dalam konteks sosial, kultural, dan filosofis yang relevan dengan nilai-nilai kemanusiaan. Literasi humanitas dapat memberdayakan dan meningkatkan kualitas individu, keluarga, masyarakat yang bersifat memberikan efek untuk ranah yang sangat luas untuk membantu memberantas kemiskinan, mengurangi angka kematian anak, pertumbuhan penduduk, menjamin pembangunan berkelanjutan, dan terwujudnya perdamaian (Gaj \& Machtinger, 2006; Tornero \& Varis, 2010; Varis, 2010).

Literasi humanitas menjadi hal yang penting dalam bertahan di era ini, tujuannya adalah agar manusia bisa berfungsi dengan baik di lingkungan manusia dan dapat memahami interaksi dengan sesama manusia (Alvermann, 2002; Diaz \& Walsh, 2018; Qiyou, 2017). Literasi humanitas adalah menjadi akhir dari literasi data dan teknologi karena pada hakikatnya seorang pembelajar abad ke-21 adalah sumber daya manusia yang melek data dan teknologi, serta mampu menggunakannya untuk hidup yang lebih mulia (Budimansyah et al., 2019). Interaksi tersebut dapat dilihat di dunia pendidikan khususnya di lingkungan sekolah. Untuk itu, tugas dunia pendidikan saat ini melalui proses pembelajarannya bukan hanya menekankan pada penguatan kompetensi literasi lama, tetapi secara simultan mengokohkan pada penguatan literasi baru yang menyatu dalam penguatan kompetensi bidang keilmuan dan keahlian atau profesi (Khlaisang \& Koraneekij, 2019), literasi humanitas yang saat ini menjadi trend pengimplementasian dalam menghadapi revolusi industri 4.0 (Deliani et al., 2018; Sanjayanti et al., 2018). Maka literasi humanitas adalah kemampuan manusia untuk mewadahi, mengelola literasi data dan teknologi dalam konteks sosial, kultural, dan filosofis yang relevan dengan nilai-nilai kemanusiaan untuk dapat memberdayakan dan meningkatkan kualitas hidup untuk menciptakan kebahagiaan dan menjamin pembangunan berkelanjutan dan terwujudnya perdamaian.

\section{Keadaaban Publik}

Keadaban publik dibentuk melalui tiga unsur, yakni keinginan untuk hidup bersama, empati, dan kepatuhan pada aturan yang adil. Ketiganya merupakan unsur yang melengkapi dalam keadaban 
publik. Tanpa keadaban publik maka kehidupan di masyarakat tidak akan nyaman. Kegelisahan dan konflik sosial akan menjadi bagian dari rutinitas warga, sebagaimana permasalahan yang ada di masyarakat tentang pertanahan, dan lain-lain. Dasar dari keadaban publik adalah suatu kebutuhan untuk hidup bersama. Dalam arti kebersamaan dalam hubungan antar sosial, bertetangga, saling menghormati antara hak sesama warga negara Indonesia.

Hal-hal yang mendasari kehidupan yang berkedaban publik adalah: Pertama, empati. Empati merupakan rasa yang harus dimiliki oleh sesama warga negara. Pemahaman terhadap kondisi orang lain dan kondisi diri sendiri harus dimunculkan dalam diri setiap manusia Indonesia. Dengan berempati maka akan dapat menjalankan kehidupan bernegara dan bermasyarakat dengan sejahtera yang berkeadilan sosial.

Kedua, kepatuhan hukum. Keinginan untuk hidup bersama dan empati sosial adalah dasar kehidupan bersama. Adanya persamaan hak dan kewajiban bagi warga negara merupakan suatu kesepakatan berkehidupan yang harus ditaati oleh semua warga negara. Dengan memahami bahwa semua manusia Indonesia mempunyai hukum yang sama di hadapan aturan yang disepakatinya maka kehidupan di negera ini akan berlangsung dengan keamanan dan tidak muncul kekhawatiran.

Ketiga, Keinginan hidup bersama. Berbagai petistiwa muncul di masyarakat, landasan kehidupan sosial di masyarakat adalah moral, politis, dan aturan yang di sepakati bersama antara masyarakat. Ketakutan yang muncul di masyarakat adalah karena perilaku yang tidak beradab ditunjukkan di muka umum, sehingga muncul ketakutan-ketakutan yang terjadi dalam diri masyarakat. Ketakutan inilah yang membuat tidak tenangnya kehidupan bemegara dan bermasyarakat yang berm artabat dengan mengedepankan saling menghargai dan jujur, sehingga keadaban publik dapat dimunculkan di negera ini (Fu'adi, 2016).

\section{Literasi Humanitas dalam Menumbuhkembangkan Kecerdasan Kewargaan}

Robohnya keadaban publik di Indonesia tidak terlepas dari berbagai macam aspek yang melatarbelakangi salah satunya adalah aspek moral. Moralitas bangsa Indonesia pada saat ini masih terus diuji, banyaknya masalah atau kejadian yang mengoyak rasa kemanusiaan bangsa Indonesia khususnya warga negara Indonesia. Tingginya angka kriminalitas baik yang diasebabkan oleh aspek ekonomi, sosial, politik, maupun moral. Tingginya angka kemiskinan, kenakalan remaja serta korupsi yang merajalela membuat pendidikan menjadi tumpuan yang diharapkan dapat membawa perubahan ke arah yang lebih baik. Peran pendidikan khususnya pendidikan kewarganegaraan menjadikan tumpuan bagi semua masyarakat yang menginginakan kemakmuran, ketenangan, dan kesejahteraan yang berdasarkan Pancasila. Peran pendidikan dalam hal ini pendidikan kewarganegaraan sangat mendukung supaya perilaku atau sikap yang kurang beradab dapat dicegah, pendidikan kewarganegaraan bukan hanya menjadi suatu teori dalam pembelajaran tetapi harus diaplikasikan dalam hidup bermasyarakat.

Berkaitan dengan literasi humanitas, World Economic Forum merilis 10 keterampilan (skill) yang harus dimiliki oleh generasi muda agar mereka mampu menghadapi perubahan di masa depan, terutama dengan adanya Era Industri 4.0 ini . Di antara keterampilan yang harus mereka miliki, antara lain: kemampuan menyelesaikan persoalan yang rumit, pemikiran kritis, kreativitas, pengelolaan emosional, kemampuan berkoordinasi dengan orang lain (teamwork), kemampuan mengambil keputusan, jiwa pelayanan, berunding, dan fleksibilitas kognitif (Anggresta, 2019). Berdasarkan Permendikbud Nomor 23 Tahun 2017 tentang Hari Sekolah, ada beberapa hal yang dikuatkan dari Kurikulum 2013 hasil revisi tahun 2017 yaitu (1) penguatan pendidikan karakter, (2) penguasaan literasi, dan (3) penguatan berpikir tingkat tinggi atau high order thinking skills. Sementara karakter dititikberatkan pada aspek religiusitas, nasionalisme, kemandirian, gotong royong dan integritas. Dalam penguasaan literasi ditekankan pada literasi abad 21 yang terangkum dalam 4C, yaitu (1) creative, (2) critical thinking, (3) communicativedan (4) collaborative (Muliastrini, 2019).

Literasi humanitas menjadi hal yang penting dalam bertahan di era ini, tujuannya adalah agar manusia bisa berfungsi dengan baik di lingkungan manusia dan dapat memahami interaksi dengan sesama manusia. Literasi humanitas adalah menjadi akhir dari literasi data dan teknologi karena pada hakikatnya seorang pembelajar abad ke-21 adalah sumber daya manusia yang melek data dan teknologi, serta mampu menggunakannya untuk hidup yang lebih mulia. Interaksi tersebut dapat 
dilihat di dunia pendidikan khususnya di lingkungan sekolah. Untuk itu, tugas dunia pendidikan saat ini melalui proses pembelajarannya bukan hanya menekankan pada penguatan kompetensi literasi lama, tetapi secara simultan mengokohkan pada penguatan literasi baru yang menyatu dalam penguatan kompetensi bidang keilmuan dan keahlian atau profesi, literasi humanitas yang saat ini menjadi trend pengimplementasian dalam menghadapi revolusi industri 4.0 . Pola Pembelajaran Literasi Humanitas Untuk Mengembangkan Kecerdasan Kewargaan dapat dilihat dalam gambar.

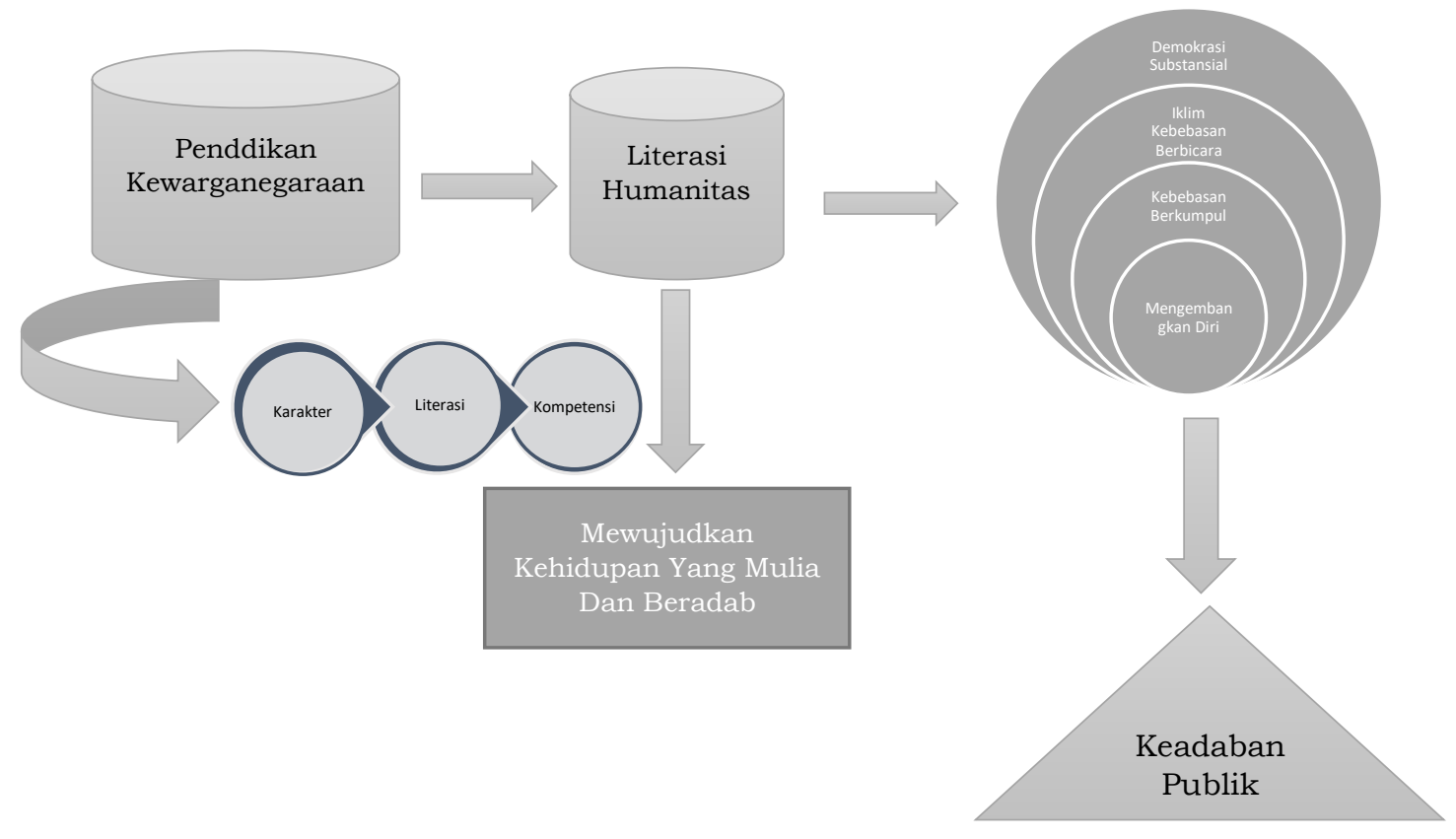

Gambar 1

Pola Pembelajaran Literasi Humanitas Untuk Mengembangkan Kecerdasan Kewargaan

Untuk menumbuhkan sikap atau perilaku yang mencerminkan literasi humanitas maka diperlukan suatu proses pendidikan yang relatif sesuai dengan konsep pendidikan yang berfungsi membentuk warga negara yang berkarakter, yaitu Pendidikan Kewarganegaraan (Budimansyah et al., 2019; Glover, 2003). Keterkaitan Pendidikan Kewarganegaraan terhadap pengembangan karakter dikemukakan oleh Winataputra, bahwa pendidikan kewarganegaraan memiliki dimensi-dimensi yang tidak bisa dilepaskan dari aspek pembentukan karakter dan moralitas publik. Pendidikan kewarganegaraan bertujuan untuk membangun karakter (character building) Bangsa Indonesia yang antara lain:

a. Membentuk kecakapan partisipasi warga negara yang bermutu dan bertanggung jawab dalam kehidupan berbangsa dan bernegara.

b. Menjadikan warga negara yang cerdas, aktif dan demokratis, namun tetap memiliki komitmen menjaga persatuan dan integritas bangsa, dan

c. Mengembangkan kultur demokrasi yang berkeadaban, yaitu kebebasan, persamaan, toleransi, dan bertanggung jawab (Somantri \& Udin Saripudin Winataputra, 2017).

Oleh karena itu, pendidikan kecerdasan kewargaan berlandaskan Pancasila merupakan solusi terbaik untuk membentuk keadaban publik. Pengembangan kecerdasan kewargaan lebih fundamental bagi suatu bangsa (Latif, 2015), untuk itu perlu dikembangkan suatu literasi yang mampu mengantarkan untuk mencapai hidup yang lebih mulia dan beradab, yaitu literasi humanitas. Literasi humanitas menumbuhkembangkan kecerdasan kewargaan dengan menciptakan kebebasan berbicara, berkumpul, dan mengembangkan diri. Kebebasan yang dimaksud sejatinya bukan sekadar pemenuhan hak namun kebebasan juga memberi ruang toleransi yang memungkinkan berkembangnya kesediaan mengapresiasi pendapat dan karya orang lain. Selain itu corak politik yang berlangsung juga mewarnai tumbuhnya kecerdasan kewargaan. Demokrasi prosedural hanya akan berhenti pada sebatas ritual atau perayaan pemilihan umum dengan hanya berganti peraturan dan 
desain kelembagaan politik yang tidak memiliki kesesuaian bagi kreativitas dan kecerdasan kewargaan (Budimansyah, 2021).

Untuk itu diperlukan suatu demokrasi sejati atau yang sering disebut demokrasi substansial yang mengandung iklim kebebasan yang lebih luas dan sehat. Dalam demokrasi substansial dimana kota-kota tumbuh kreatif menjadi pusat daya tarik berkumpulnya orang yang kreatif, cerdas, dan berpandangan ke masa depan dengan semangat saling menghormati, logis, dan mempunyai moral publik yang baik. Kondisi tersebut dapat dicirikan dengan adanya budaya literasi yang kuat, semangat solidaritas, cinta tanah air, bela negara pemimpin menjadi teladan, dan warga negara menjadi garda republik. Kecerdasan kewargaan menjadi prasyarat membangun keadaban publik melalui sistem demokrasi substansial yang mengandung iklim kebebasan yang lebih luas dan sehat. Dalam alam demokrasi dengan keadaban publik terbangun sikap dan perilaku yang menghargai, menghormati, peduli dengan orang lain, taat pada peraturan, dan norma sosial, serta menerapkannya dalam hubungan sosial dalam kehidupan, bermasyarakat, berbangsa dan bernegara (Budimansyah, 2021; Somantri \& Saripudin Winataputra, 2017). Proses pengembangan kecerdasan kewargaan berbasis literasi humanitas membangun keadaban publik dapat di lihat dalam tabel 1.

Tabel 1

Proses Pembelajaran Pengembangan Kecerdasan Kewargaan Berbasis Literasi Humanitas Membangun Keadaban Publik

\begin{tabular}{|c|c|c|c|c|}
\hline Mata Kuliah & \multicolumn{4}{|c|}{ Pendidikan Kewarganegaraan } \\
\hline Topik & \multicolumn{4}{|c|}{ Hak Asasi Manusia } \\
\hline Sikap & \multicolumn{4}{|c|}{ Perilaku Warga Negara Yang Muncul } \\
\hline $\begin{array}{l}\text { Keterampilan } \\
\text { Abad } 21\end{array}$ & & Literasi Humanitas & $\begin{array}{l}\text { Kecerdasan } \\
\text { Kewargaan }\end{array}$ & $\begin{array}{c}\text { Keadaban } \\
\text { Publik }\end{array}$ \\
\hline \multirow[t]{4}{*}{ Kompetensi } & $\begin{array}{l}\text { Keterampilan } \\
\text { berpikir kritis }\end{array}$ & \multirow{4}{*}{$\begin{array}{l}\text { Sikap yang muncul } \\
\text { adalah warga negara } \\
\text { yang mampu } \\
\text { memanfaatkan data dan } \\
\text { teknologi untuk dapat } \\
\text { dimanfaatkan sesuai } \\
\text { dengan kebutuhan, } \\
\text { contoh hak untuk } \\
\text { berserikat dan } \\
\text { berkumpul, sebagai } \\
\text { warga negara yang } \\
\text { mampu berpikir kritis } \\
\text { maka akan berorganisasi } \\
\text { untuk tujuan } \\
\text { pengembangan dan } \\
\text { pematangan diri untuk } \\
\text { hidup dalam masyarakat }\end{array}$} & \multirow[b]{4}{*}{$\begin{array}{l}\text { Sikap yang muncul } \\
\text { memahami hak dan } \\
\text { kewajibannya } \\
\text { sebagai anggota } \\
\text { sebuah organisasi. } \\
\text { kebebasan } \\
\text { berbicara, } \\
\text { berkumpul, dan } \\
\text { mengembangkan } \\
\text { diri. Kebebasan } \\
\text { yang dimaksud } \\
\text { sejatinya bukan } \\
\text { sekadar pemenuhan } \\
\text { hak namun } \\
\text { kebebasan juga } \\
\text { memberi ruang } \\
\text { toleransi ang } \\
\text { memungkinkan } \\
\text { berkembangnya } \\
\text { kesediaan } \\
\text { mengapresiasi } \\
\text { pendapat dan karya } \\
\text { orang lain. }\end{array}$} & \multirow{4}{*}{$\begin{array}{l}\text { Sikap yang } \\
\text { muncul } \\
\text { keinginan untuk } \\
\text { hidup bersama, } \\
\text { empati, dan } \\
\text { kepatuhan pada } \\
\text { aturan yang adil } \\
\text { dalam hidup } \\
\text { bermasyarakat }\end{array}$} \\
\hline & Kreatif & & & \\
\hline & Komunikasi & & & \\
\hline & Kolaborasi & & & \\
\hline \multirow[t]{6}{*}{ Literasi } & Baca tulis & \multirow{6}{*}{$\begin{array}{l}\text { Sikap yang muncul } \\
\text { adalah Kecerdasan } \\
\text { intelektual juga ditandai } \\
\text { dengan kemampuan } \\
\text { membina ketertiban. } \\
\text { Setelah adanya budaya } \\
\text { membaca siswa mampu } \\
\text { menggunakan hak yang } \\
\text { dimiliki sesuai dengan } \\
\text { kaidah-kaidah normatif } \\
\text { yang berlaku. }\end{array}$} & \multirow{6}{*}{$\begin{array}{l}\text { Sikap yang muncul } \\
\text { adalah Warga } \\
\text { negara cerdas } \\
\text { memilki peran } \\
\text { penting untuk } \\
\text { berkiprah secara } \\
\text { optimal dalam } \\
\text { rangka mengangkat } \\
\text { kembali bangsa } \\
\text { Indonesia menuju } \\
\text { peradaban baru }\end{array}$} & \multirow{6}{*}{$\begin{array}{l}\text { Sikap yang } \\
\text { muncul } \\
\text { keinginan untuk } \\
\text { hidup bersama, } \\
\text { empati, dan } \\
\text { kepatuhan pada } \\
\text { aturan yang adil } \\
\text { dalam hidup } \\
\text { bermasyarakat }\end{array}$} \\
\hline & Numerasi & & & \\
\hline & Sains & & & \\
\hline & Digital & & & \\
\hline & Finansial & & & \\
\hline & $\begin{array}{l}\text { Budaya } \\
\text { kewargaan }\end{array}$ & & & \\
\hline
\end{tabular}




\begin{tabular}{|c|c|c|c|c|}
\hline & & $\begin{array}{l}\text { Menghargai hak dan } \\
\text { kewajiban serta } \\
\text { kepentingan orang lain. } \\
\text { Tidak memaksakan } \\
\text { kehendak kepada orang } \\
\text { lain, seperti pendapat, } \\
\text { ide, pikiran, dan } \\
\text { sebagainya. Aspek } \\
\text { kecerdasan intelektual } \\
\text { juga ditandai oleh } \\
\text { mampu berkomunikasi. } \\
\text { Kualitas komunikasi, } \\
\text { bahasa, dan etika dalam } \\
\text { berbicara dari para siswa } \\
\text { yang rajin membaca } \\
\text { lebih baik dari pada } \\
\text { siswa yang malas } \\
\text { membaca. Selain } \\
\text { kualitas komunikasi } \\
\text { yang membaik, konten } \\
\text { yang dibicarakan pun } \\
\text { lebih positif dan } \\
\text { bermanfaat. }\end{array}$ & $\begin{array}{l}\text { yang lebih modern } \\
\text { dan demokratis. } \\
\text { Dengan warga } \\
\text { negara yang cerdas } \\
\text { itu disamping akan } \\
\text { mengangkat } \\
\text { martabat bangsa, } \\
\text { juga akan } \\
\text { menjadikan bangsa } \\
\text { Indonesia sebagai } \\
\text { negara dan bangsa } \\
\text { yang kompetitif } \\
\text { dalam percaturan } \\
\text { global saat ini. }\end{array}$ & \\
\hline \multirow{7}{*}{$\begin{array}{l}\text { Karakter yang } \\
\text { kuat }\end{array}$} & Iman dan takwa & \multirow{7}{*}{$\begin{array}{l}\text { Sikap yang muncul } \\
\text { adalah kemampuan } \\
\text { menghindari perilaku } \\
\text { moral yang buruk yang } \\
\text { bertentangan dengan } \\
\text { nilai-nilai moralitas } \\
\text { masyarakat. Setelah } \\
\text { diberlakukannya } \\
\text { gerakan literasi ini, } \\
\text { siswa menjadi } \\
\text { senantiasa berbuat baik, } \\
\text { senantiasa toleransi } \\
\text { terhadap perbedaan, dan } \\
\text { memiliki sifat jujur. }\end{array}$} & \multirow{7}{*}{$\begin{array}{l}\text { Sikap yang muncul } \\
\text { adalah kemampuan } \\
\text { seseorang untuk } \\
\text { memainkan peran } \\
\text { dirinya secara } \\
\text { proaktif sebagai } \\
\text { warga negara dan } \\
\text { warga masyarakat } \\
\text { dalam tata } \\
\text { kehidupan yang } \\
\text { kompleks dengan } \\
\text { berbasiskan identitas } \\
\text { normatif bangsa. } \\
\text { Seseorang yang } \\
\text { memiliki kecerdasan } \\
\text { kewarganegaraan } \\
\text { akan menunjukkan } \\
\text { performance sebagai } \\
\text { warga negara yang } \\
\text { peduli terhadap } \\
\text { kondisi sosial, jujur } \\
\text { dalam menyikapi } \\
\text { berbagai fenomena } \\
\text { yang ada, kritis } \\
\text { terhadap kondisi } \\
\text { yang ada, serta } \\
\text { tangguh dalam }\end{array}$} & \multirow{7}{*}{$\begin{array}{l}\text { Sikap yang } \\
\text { muncul } \\
\text { keinginan untuk } \\
\text { hidup bersama, } \\
\text { empati, dan } \\
\text { kepatuhan pada } \\
\text { aturan yang adil } \\
\text { dalam hidup } \\
\text { bermasyarakat }\end{array}$} \\
\hline & Rasa ingin tahu & & & \\
\hline & Inisiatif & & & \\
\hline & Kegigihan & & & \\
\hline & $\begin{array}{l}\text { Kemampuan } \\
\text { beradaptasi }\end{array}$ & & & \\
\hline & Kepemimpinan & & & \\
\hline & $\begin{array}{l}\text { Kesadaran sosial } \\
\text { dan budaya }\end{array}$ & & & \\
\hline
\end{tabular}

\section{Simpulan}

Pendidikan merupakan salah satu proses membentuk manusia Indonesia yang cerdas sekaligus berkarakter. Kondisi tersebut sesuai dengan fungsi dan tujuan Pendidikan Nasional yang tercantum dalam Undang-Undang Nomor 20 Tahun 2003 Bab 2 Pasal 3, disebutkan bahwa Pendidikan Nasional berfungsi mengembangkan kemampuan dan membentuk watak serta peradaban bangsa yang bermartabat dalam rangka, mencerdaskan kehidupan bangsa, bertujuan untuk berkembangnya potensi peserta didik agar menjadi manusia yang beriman dan bertakwa kepada Tuhan Yang Maha 
Esa, berakhlak mulia, sehat, berilmu, cakap, kreatif, mandiri, dan menjadi warga negara yang demokratis serta bertanggung jawab, untuk itu diperlukan suatu literasi yang mempu untuk mewujudkan tujuan tersebut dalam kehidupan nyata. Literasi tersebut adalah literasi humanitas.

Literasi humanitas menjadi hal yang penting dalam bertahan di era ini, tujuannya adalah agar manusia bisa berfungsi dengan baik di lingkungan manusia dan dapat memahami interaksi dengan sesama manusia. Literasi humanitas adalah menjadi akhir dari literasi data dan teknologi karena pada hakikatnya seorang pembelajar abad ke-21 adalah sumber daya manusia yang melek data dan teknologi, serta mampu menggunakannya untuk hidup yang lebih mulia. Interaksi tersebut dapat dilihat di dunia pendidikan khususnya di lingkungan sekolah. Untuk itu, tugas dunia pendidikan saat ini melalui proses pembelajarannya bukan hanya menekankan pada penguatan kompetensi literasi lama, tetapi secara simultan mengokohkan pada penguatan literasi baru yang menyatu dalam penguatan kompetensi bidang keilmuan dan keahlian atau profesi, literasi humanitas yang saat ini menjadi trend pengimplementasian dalam menghadapi revolusi industri 4.0

Untuk menumbuhkan sikap atau perilaku yang mencerminkan literasi humanitas maka diperlukan suatu proses pendidikan yang relatif sesuai dengan konsep pendidikan yang berfungsi membentuk warga negara yang berkarakter, yaitu Pendidikan Kewarganegaraan. Keterkaitan Pendidikan Kewarganegaraan terhadap pengembangan karakter dikemukakan oleh Winataputra, bahwa pendidikan kewarganegaraan memiliki dimensi - dimensi yang tidak bisa dilepaskan dari aspek pembentukan karakter dan moralitas publik. Pendidikan kewarganegaraan bertujuan untuk membangun karakter (character building) Bangsa Indonesia yang antara lain:

a. Membentuk kecakapan partisipasi warga Negara yang bermutu dan bertanggung jawab dalam kehidupan berbangsa dan bernegara.

b. Menjadikan warga Negara yang cerdas, aktif dan demokratis, namun tetap memiliki komitmen menjaga persatuan dan integritas bangsa, dan,

c. Mengembangkan kultur demokrasi yang berkeadaban, yaitu kebebasan, persamaan, toleransi, dan bertanggung jawab (Somantri \& Udin Saripudin Winataputra, 2017).

Kecerdasan kewargaan menjadi prasyarat membangun keadaban publik melalui sistem demokrasi substansial yang mengandung iklim kebebasan yang lebih luas dan sehat. Dalam alam demokrasi dengan keaadaban publik terbangun sikap dan perilaku yang menghargai, menghormati, dan peduli dengan orang lain, taat pada peraturan, dan norma sosial serta menerapkannya dalam hubungan sosial dalam kehidupan, bermasyarakat, berbangsa, dan bernegara (Budimansyah, 2021; Somantri \& Saripudin Winataputra, 2017). Oleh karena itu, pendidikan kecerdasan kewargaan berlandaskan Pancasila merupakan solusi terbaik untuk membentuk keadaban publik. Pengembangan kecerdasan kewargaan lebih fundamental bagi suatu bangsa (Latif, 2015), untuk itu perlu dikembangkan suatu literasi yang mampu mengantarkan untuk mencapai hidup yang lebih mulia dan beradab, yaitu literasi humanitas. Literasi humanitas merupakan muara dari literasi data dan teknologi bagi pembelajar abad 21 untuk kehidupan yang lebih mulia dan beradab. Pendidikan Kewarganegaraan memiliki peran sentral dalam membangun kualitas pendidikan di Indonesia, khususnya pengembangan literasi manusia.

\section{Referensi}

Alvermann, D. E. (2002). Effective Literacy Instruction for Adolescents. Journal of Literacy Research, 34(2), 189-208. https://doi.org/10.1207/s15548430j1r3402_4

Anggresta, V. (2019). Literasi Manusia Untuk Menyiapkan Mahasiswa Yang Kompetitif Di Era Industri 4.0. Ilmiah Kependidikan, 6(3), 217-222.

Budimansyah, D. (2008). Peningkatan Mutu Pendidikan Melalui Penguatan Partisipasi Masyarakat. Educationist, 2(1), 56-63. Diambil dari http://ejournal.sps.upi.edu/index.php/educationist/article/view/35

Budimansyah, D. (2021). Kecerdasan Kewargaan (Vol. 3, hal. 1-12). Yogyakarta: Universitas Ahmad 
Dahlan.

Budimansyah, D., Suharto, N., \& Nurulpaik, I. (2019). Proyek Belajar Karakter Untuk Mengembangkan Literasi Baru Abad 21. Gapura Press (Cetakan pe, Vol. 1). Bandung: Gapura Press. https://doi.org/10.1017/CBO9781107415324.004

Davenport, C. A., Watson, M., \& Cannon, J. E. (2019). Single-Case Design Research on Early Literacy Skills of Learners Who Are d/Deaf and Hard of Hearing. Journal American Annals of the Deaf, 164(3), 363-380. https://doi.org/10.1353/aad.2019.0018

Deliani, S., Sulistyawati, S., \& Kurniawan, B. (2018). Pembentukan Karakter Melalui Literasi dari Aspek Satra dan Budaya di Desa Manik Maraja Kec Sarimatondang Kabupaten Sidamanik. In Prosiding Seminar Nasional Hasil Pengabdian (hal. 156-160).

Diaz, S., \& Walsh, A. (2018). Promoting Evidence-Based Practice and Information Literacy through an Undergraduate Nursing Journal Club. Journal Pennsylvania Libraries: Research \& Practice, 6(1), 23-38. https://doi.org/10.5195/palrap.2018.171

Fu'adi, A. (2016). Peran Pendidikan Agama Dalam Membentuk Manusia Yang Berkeadaban Publik. Millah, XI(2), 559-578. https://doi.org/10.20885/millah.volxi.iss2.art11

Gaj, N., \& Machtinger, E. (2006). Understandings of literacy. Journal Education for All Global Monitoring Report 200 6, 14(10/11), 1-13. https://doi.org/10.2307/4022716

Glover, J. (2003). Humanity: A Moral History of the Twentieth Century (review). Hypatia (Vol. 18). London: YALE NOTA BENE YALE UNIVERSITY PRESS NEW HAVEN AND LONDON. https://doi.org/10.1353/hyp.2003.0041

Khlaisang, J., \& Koraneekij, P. (2019). Open online assessment management system platform and instrument to enhance the information, media, and ICT literacy skills of 21 st century learners. International Journal of Emerging Technologies in Learning, 14(7), 111-127. https://doi.org/10.3991/ijet.v14i07.9953

Latif, Y. (2015). Kecerdasan Kewargaan. Kompas , 6 Oktober 2015.

Masrukhi. (2018). Pengembangan Civic Intelligence Berbasis Kegiatan Ekstrakurikuler di Sekolah Dasar. Jurnal Integralistik, 29(1), 14-15.

Muktaf, Z. M. (2016). T eknik Penelitian Studi Kasus, Etnografi dan Fenomenologi dalam Metode Kualitatif. Jurnal Pendidikan, 3(1), 1-5.

Muliastrini, N. K. E. (2019). Penguatan Literasi Baru (Literasi Data, Teknologi, dan SDM/Humanisme) Pada Guru-Guru Sekolah Dasar Dalam Menjawab Tantangan Era Revolusi Industri 4.0. In Prosiding STKIP Agama Hindu Amlapura 2019 (hal. 88-102). Denpasar.

Munif, J. A. (2017). Robohnya keadaban publik. Beritagar, 14 Agustus 2017.

Qiyou, S. (2017). Research on Humanistic Literacy Education for Higher Vocational Student Majoring in Art Design. In 2016 International Conference on Humanities Science, Management and Education Technology (HSMET 2016) ISBN: 978-1-60595-394-6 (hal. 115-119). https://doi.org/10.12783/dtssehs/hsmet2016/10265

Rohman, B., \& Jarudin. (2021). Android Based Interactive Media For Civic Intellegence Diffusion In Al Quran Perspective. Journal Of Southwest Jiaotong University, Vol 56 No(2005), 1-21.

Sanjayanti, Qondias, Wardana, \& Darmayanti. (2018). Diagnosa Literasi Humanistik dalam Model Pembelajaran Konstruktivis pada Mahasiswa Politeknik Ganesha Guru. In Seminar Nasional Riset Inovatif 2018 (hal. 92-96). Mataram: Senari-6.

Schuler, D. (2014). Pieces of Civic Intelligence: Towards a capacities framework. E-Learning and Digital Media, 11(5), 518-529. https://doi.org/10.2304/elea.2014.11.5.518 
Somantri, M. N., \& Saripudin Winataputra, U. (2017). Disiplin Pendidikan Kewarganegaraan: Kultur Akademis dan Pedagogis. (Sapriya \& R. Machfiroh, Ed.) (Edisi pert). Bandung: Laboratorium Pendidikan Kewarganegaraan Universitas Pendidikan Indonesia.

Somantri, M. N., \& Udin Saripudin Winataputra. (2017). Disiplin Pendidikan Kewarganegaraan Kultur Akademik dan Pedagogis. (Sapriya, Ed.) (Edisi pert). Bandung: Penerbit Laboratorium PKn, Bandung.

Sugiyono. (2015). Metode Penelitian Pendidikan: Pendekatan Kuantitatif, Kualitatis, dan R\&D. Bandung: Alfabeta.

Tornero, J. M. P., \& Varis, T. (2010). Media Literacy and New Humanism. Director. Moscow: Published by the UNESCO Institute for Information Technologies in Education.

Varis, T. (2010). Towards global education: The need for the 21 st century literacies. International Conference IITE-2010, 1-12. Diambil dari http://www.iite.unesco.org/files/conference2010/Towards global education.pdf 